\title{
PEDAGOGY
}

\section{НЕЙРОСТИМУЛЯЦИЙНІ ТЕХНОЛОГІї У ЛОГОПЕДИЧНІЙ ПРАКТИЦІ 3 ДІТЬМИ ДОШКІЛЬНОГО ВІКУ З ТЯЖКИМИ ПОРУШЕННЯМИ МОВЛЕННЯ}

\author{
Наталія Лопатинська \\ Кандидат педагогічних наук, Україна, Запоріжжя, Хортицька національна академія
}

DOI: https://doi.org/10.31435/rsglobal_ijitss/31032020/7011

\begin{abstract}
ARTICLE INFO
Received 10 January 2020

Accepted 15 March 2020

Published 31 March 2020

\section{KEYWORDS}

neurostimulation, neurotechnology, neurology, correction activities.

ABSTRACT

Article reveal practical need for integration and accumulation of the knowledge in neurology, neurophysiology, neuroanatomy, neurochemistry, neuropsychology, neuropsycholinguistics for reorientation of modern logopedic practice in a narrow-disciplinary discipline. An attempt has been made to generalize the multidisciplinary research of scientists and practitioners devoted to the problems of the search for neurostimulation technologies. Author's disclosure of the experience of using modern neurostimulation technologies: neurophysiotherapy, neuroacoustic, neurologic is becoming a particular relevance. According to the results of the dynamics analysis of electrophysiological, psychological and logopedic indicators after the practical introduction of neurotechnology, positive changes in the functional state of the brain were confirmed, which contributed to the activation of the neural networks of the speech and communicative mechanism. It is generalized that the use of neurostimulation technologies in preschool-age children with different types of speech dysontogenesis is a new step in optimizing the process of children speech correction and a prerequisite for further use of classical techniques of speech therapy and steps in reaching the maximum possible results.
\end{abstract}

Citation: Наталія Лопатинська. (2020) Neirostymuliatsiini Tekhnolohii u Lohopedychnii Praktytsi z Ditmy Doshkilnoho Viku z Tiazhkymy Porushenniamy Movlennia. International Journal of Innovative Technologies in Social Science. 3(24). doi: 10.31435/rsglobal_ijitss/31032020/7011

Copyright: (C) 2020 Наталія Лопатинська. This is an open-access article distributed under the terms of the Creative Commons Attribution License (CC BY). The use, distribution or reproduction in other forums is permitted, provided the original author(s) or licensor are credited and that the original publication in this journal is cited, in accordance with accepted academic practice. No use, distribution or reproduction is permitted which does not comply with these terms.

Вступ. Сучасний стан здоров'я дітей України, за даними Українського інституту стратегічних досліджень Міністерства охорони здоров'я України та Державної служби статистики України [13] свідчить про негативну тенденцію захворюваності та поширеності хвороб серед дитячого населення. На тлі зменшення дитячого населення (1997 - 12124,4 тис. осіб; 2007 - 8536,1 тис. осіб; 2017 - 7615,6 тис. осіб) [13] «у структурі інвалідності дітей упродовж 2012-2016 рр. серед причин, внаслідок яких діти стають інвалідами, перше місце посідають природжені вади розвитку, деформації та хромосомні аномалії (30,0-31,1\%), друге хвороби нервової системи (17,9-16,6\%), трете - розлади психіки та поведінки $(13,9-14,4 \%) »$ $[13$, С. 66]. До найпоширеніших детермінантів нейроонтогенезу центральної нервової системи науковці (Ю. Антипкін, Л. Арабська, Н. Гойда, Г. Даниленко, О. Дудіна, О. Лук'янова, В. Мартинюк, Р. Моісєнко, Л. Пономарьова, С. Толкач та ін.) відносять перинатальну патологію, зростання генетичних мутацій, поєднання несприятливих факторів перебігу вагітності та погіршення екологічної обстановки, наслідками яких $\epsilon$ функціональна 
неспроможність інтегруючих систем регуляції, які забезпечують адаптованість та цілісність перебігу життєвих процесів в організмі, та ураження життєво важливих функцій, охоплюючи вищі психічні функції, в тому числі й усі види мовлення. Тому, зростаюча кількість дітей із тяжкими порушеннями мовлення різних генезів, ускладненими поведінковими розладами, аутистичними рисами, генетичними синдромами, порушеннями метаболізму в нейроструктурах центральної нервової системи, обумовлює необхідність ширшого впровадження сучасних нейрофізіотерапевтичних i нейропсихологічних методів i методик у практику корекційнорозвиткової діяльності. Органічність генезу мовленнєвих патологій проявляється у диспраксіях iз м'язевою та іннерваційною недостатністю, мовленнєвих дистаксіях та дисгнозіях, що є, 3 психологічного аспекту симптомами ураження вищих психічних функцій, медичного порушенням мінімальної мозкової дисфункції. У зв'язку з цим, актуальною є переорієнтація сучасної логопедичної практики з вузькодисциплінарної на трансдисциплінарну, що дозволить підвищити ефективність комплексної діагностики та корекції мовленнєвих патологій.

Результати досліджень. Про необхідність інтеграції та акумулювання накопичених знань 3 неврології, нейрофізіології, нейроанатомії, нейрохімії, нейропсихології, нейропсихолінгвістики зазначали українські науковці: С. Миронова, Н. Пахомова, В. Синьов, Є. Синьова, Д. Супрун, С. Федоренко, Л. Фомічова, А Шевцов, М. Шеремет, Д. Шульженко. Ними акцентовано увагу на тому, що накопичений мультидисциплінарний досвід у кожній зазначеній науці давно на практиці вийшов за рамки міждисциплінарності.

Саме завдяки взаємодії традиційних методик корекції компонентів мовлення 3 сучасними нейрологокорекційними технологіями, спрямованими на відновлення функціональної системи мови і мовлення в цілому, реалізується функціонально-системний підхід до організації та надання нейрологопедичної допомоги.

Сьогодні важливим $\epsilon$ усвідомлення того, що проблемам мозкових стимуляцій певних анатомічних структур головного мозку у дітей, які потребують корекції фізичного та(або) розумового розвитку, присвячені дослідження вітчизняних науковців ще на початку XIX століття. Саме в цей період на Україні активно розгортаються полідисциплінарні дослідження. Так, у працях науковців та практик представлені питання:

- онтогенезу та нейроонтогенезу мовленнєвого розвитку (В. Бельтюков, С. Бенилова, А. Богуш, О. Гвоздєв, Т. Дегтяренко, Ю. Коломієць, В. Лубовський, Н. Павлова, Н. Пахомова, Г. Розенгард-Пупко, С. Соботович, М. Супрун, Т. Ушакова, М. Шеремет, М. Швачкін та ін.); - нейрофізіологічні засади мовленнєвої діяльності - О. Боряк, С. Кондукова, I. Мартиненко, Є. Соботович, М. Шеремет та ін.;

- нейрокогнітивного онтогенезу розвитку - О. Баранов, О. Маслова; Л. НамазоваБаранова та ін.;

- нейрокінезіологічної діагностики - В. Здвижкова, В. Козявкін та ін.;

- нейрогенетичної діагностики - Н. Брагіна та ін.;

- нейропсихолінгвістичної діагностики та корекції - І. Абєлєва, Т. Ахутіна, Л. Виготський, М Жинкін, Л. Засєкіна І. Зимня, О. Леонтьєв, О. Лурія, Л. Сахарний, Л. Халілова, В. Тарасун та ін.;

- нейроортопедичної діагностики та корекції дітям із наслідками дитячого церебрального паралічу - О. Данилов, В. Машуренко, О. Крамчанінова, К. Рихлевський, В. Цимбалюк та ін.;

- нейпсихологічної сенсомоторної корекції - А. Заплатинська, А. Цвєтков та ін.;

- нейропсихологічної діагностики та корекції в дитячому віці - Т. Візель, О. Лурія, Ю. Мікадзе, К. Островська, А. Семенович, Т. Фотекова, Л. Цветкова, Д. Шульженко та ін.;

- нейропсихологічної готовності до шкільного навчання - Ю. Коломієць, І. Мартиненко,

Н. Пахомова, В. Тарасун, М. Шеремет та ін.;

- системного підходу діагностики та корекції психофізичного розвитку дітей I. Мартиненко, С. Миронова, Н. Пахомова, О. Проскурняк, В. Синьов, Є. Синьова, Д. Супрун, С. Федоренко, Л. Фомічова, А. Шевцов, М. Шеремет, Д. Шульженко та ін..

3 появою сучасних методів нейровізуалізації мозкових процесів значно розширилося коло наукових інтересів вітчизняних і зарубіжних науковців. Досягнення нейронаук дозволили аналізувати причини та механізми мовленнєвих розладів не ізольовано, поза увагою цілісного організму людини, а як єдине ціле, цілісну саморегулюючу систему з автономними критичними періодами та етапами психомоторного і мовленнєвого розвитку. Тому на сучасному етапі гострою є потреба у широкій орієнтації вчителя-логопеда в медичних знаннях, уявленнях та 
поняттях. Останнім часом спостерігаємо продуктивний трансфер медичних технологій в області нейронаук і нейротехнологій та укладення союзу між логопедією та науками про мозок. Актуалізуються нові аспекти важливості нейроонтогенетичного підходу до проблеми аномального розвитку нервової системи в цілому та ролі нейробіологічних факторів у появі порушень мовленнєвого розвитку зокрема.

На сучасному етапі розвитку логопедії зростає кількість вітчизняних (Т. Дегтяренко, Н. Павлова, В. Тарасенко та ін.) і закордонних (Н. Бурачевська, О. Бурачевська, А. Доман, В. Єфімова, О. Єфімов, А. Сиротюк, А. Томатіс, W. Dunn, B. Jenkins, J. Kerr, B. Knickerbocker, S. Lane, M. Merzenich, S. Miller, D. McIntosh, L. Miller, D. Parham, C. Royeen, C. Summer, P. Tallal i ін.) досліджень, в яких предметом наукового інтересу стають пошуки специфічних засобів впливу на функціональну систему мови і мовлення, які не тільки запускають мовномовленнєвий механізм, але й прискорюють темпи його розвитку, якісно змінюють всі компоненти мовномовленнєвої та комунікативної діяльності [1-13]. Завдяки інтеграції досягнень медицини в логопедичну теорію та практику корекції тяжких та ускладнених мовленнєвих порушень активно використовуються нейростимуляційні технології мовленнєвих зон.

За Н. Павловою, нейростимуляція мовленнєвих зон - цілеспрямований вплив високо- та низькочастотними імпульсами на певну ділянку мозку з метою відновлення втрачених зв'язків між артикуляційним, голосовим, дихальним апаратами і центральною нервовою системою та підвищення мовленнєвої активності [9].

До нейростимуляційних технологій ми віднесли:

- нейрофізіотерапевтичні програми: мікрополяризація, мозочкова стимуляція, програма сенсорної інтеграції та антигравітації, Interactive Metronome, Timocco, OmiBeam, OmiFloor [1; 3; $6 ; 7 ; 9 ; 11]$;

- нейроакустичні технології: Альфреда Томатіса (1957), Алекса Домана «The Listening Program» (1998), Алекса Домана «inTime» (2009), В. Тарасенко «Високачастотная терапія звуком» (2011), метод біологічного зворотного зв’язку [3; 5; 9; 10];

- нейропсихологічні: програми розвитку сенсомоторної інтеграції і модуляції Дж. Айріс [3-5]; терапія $[1 ; 2]$.

- нейрологопедичні програми: Fast For Word (1996), Forbrain, Speechleader, ДЕНС-

Розкриємо їх детальніше.

\section{Нейрофізіотерапевтичі технології}

Активне залучення фізіотерапевтичних технологій у корекційно-розвиткову діяльність дітей із різними типами мовленнєвого дизонтогенезу надає можливість активувати та підвищувати сприймаючу функцію нейронів, що сприяє поліпшенню координації інтрацентральних відносин та оптимізації центральної регуляції мовленнєвої функції.

Аналіз наукової літератури засвідчив, що в дослідженнях сьогодні досить широко представлено різні підходи до використання методу мікрополяризації, як унікальної нейротехнології корекції неврологічної симптоматики, який дозволяє змінювати функціональний стан відділів та ланок нервової системи. Сутність методу полягає в тому, що на тканини головного мозку впливає постійний струм вкрай малих величин (до 1мА), що забезпечує безболісну, цілеспрямовану та високоефективну стимуляцію уражених структур центральної нервової системи. Термін «мікрополяризація» вперше запропонований працівниками лабораторії Н. Бехтерової. Теоретико-методологічним підгрунтям унікального методу мікрополяризації $\epsilon$ теорія дії електричного току на нервову тканину (Б. Вериго, Л. Гальвані, Г. Гельмгольц, Е. Дюбуа-Реймон, І. Мюллер, Д. Пінчук, Ж. Пельтьє, Е. Пфлюгер, А. Шемякін, В. Чаговець, А. Чутко та ін.) $[1 ; 7 ; 11]$.

На сьогодні у країнах Європейського Союзу та пострадянського простору накопичено достатній обсяг результатів наукових досліджень (Н. Бехтерева, О. Богданов, М. Бухарцев, Г. Вартанян, Р. Гімранов, О. Горелік, Г. Вартанян, В. Ілюхіна, І. Кисельов, Н. Кожушко, Ю. Кропотов, В. Лебедев, О. Ліппольд, Ю. Матвєєв, В. Михайлов, О. Наришкін, Д. Пінчук, Т. Скоромець, Л. Чутко, О. Шелякін, В. Шуваєв, P. Boggio R. Ferrucci F. Fregni M. Lima N. Lang M. Nitsche W. Paulus S. Rigonatti та ін.), які довели позитивний вплив мікрополяризації, що не лише підвищує нейрональну активність головного мозку (як у зоні прикладання, так і в інших зонах мозку), а й змінює морфологічну структуру нейроглії, нейрону та синаптичного апарату. 
С. Бекшаєв, Д. Пінчук, С. Бумакова (2012) запатентували засіб лікування сенсорної та моторної алалії за допомогою транскраніальної мікрополяризації.

Результати дослідження Н. Павлової та В. Тарасенко констатували ефективність використання методу транскраніальної мікрополяризації, зокрема, у дітей із [9-10]:

- сенсорною алалією - покращується процес сприйняття звернутого мовлення, фонематичного слуху;

- моторною алалією відновлюється працездатність артикуляційного апарату та зростає рівень мовленнєвої активності;

- затримкою психічного розвитку у поєднанні з розладами аутистичного спектра відмічається позитивна динаміка у розвитку вищих психічних функцій та емоційно-вольової сфери;

- синдромом дефіциту уваги та гіперактивністю знижується імпульсивність та зменшується кількість випадків агресії.

Таким чином, метод транскраніальної мікрополяризації сприяє підвищенню функціональності кори головного мозку, загального та дрібного праксису.

Також, вперше на Україні В. Тарасенко використовується метод вертебральної мікрополяризації у поєднанні з оксигенотерапією. Автором дослідженнями доведено, що метод мікрополяризації коригує моторні, мовленнєві, поведінкові, когнітивні, сенсорні порушення.

3 метою запуску мовленнєвої активності у немовленнєвих дітей використовують обидві програми: нейроакустичної стимуляції та транскраніальної мікрополяризації головного мозку, але за індивідуально розробленою схемою.

Вивчивши вітчизняний і зарубіжний теоретико-практичний досвід використання методу транскраніальної мікрополяризації ми вирішили апробувати ії в нейрологокорекційній роботі 3 дітьми дошкільного віку з тяжкими порушеннями мовлення первинного і вторинного генезу (на тлі розладів аутистичного спектра і затримки психомоторного і психомовленнєвого розвитку). Метою використання методу транскраніальної мікрополяризації було активація центральної регуляції психічних функцій в цілому та мовленнєвої зокрема. Діти, у яких було зафіксовано індивідуальну непереносимість електричного струму, злоякісні пухлини, простудні та інфекційні захворювання, високу температуру тіла, щеплення, транскраніальну мікрополяризацію не проводили.

Транскраніальна мікрополяризація здійснювалась за допомогою медичного апарату гальванізатору ПОЛЯРИС. Мікрополяризаційний вплив застосовувався на будь-якому з етапів корекційно-реабілітаційної діяльності. Процедури проводилися тривалістю 20-25 хвилин 2 рази на тиждень. Тривалість одного курсу лікування складала 10-15 сеансів і базувалась на висновках аналізу патологічного симптомокомплексу, ступеня порушення розвитку дитини дошкільного віку, індивідуальної латералізації організації мозку, схильності нервової системи до виснажування внаслідок стимуляції та стан іiі компенсаторних можливостей. Положення першого електрода (анода) обиралось на підставі результатів нейропсихологічного та психо-логопедичного обстеження, другого електрода (катоду) фіксувалось на соскоподібному відростку або потилиці. Обробка результатів грунтувалась на показниках електроенцефалографії, психологопедичного обстеження, суб'єктивних звітах фасилітаторів (батьків, спеціалістів).

Аналіз динаміки електрофізіологічних, психологічних i логопедичних показників засвідчує позитивні зміни функціонального стану головного мозку. Після проведеного курсу транскраніальної мікрополяризації у дітей із тяжкими порушеннями мовлення спостерігалась позитивна динаміка у функціонуванні структур:

- I функціонального блоку головного мозку: загальна психомоторна активність (подовження періоду активності, оволодіння новими руховими паттернами, поліпшення координації рухів, мілкої моторики), орієнтовно-дослідницька діяльність (поява вказівного жесту, мотивація досліджувати предмети навколишнього оточення), когнітивний інтерес, працездатність та продуктивність діяльності;

- II функціонального блоку: зрушення у сенсорно-перцептивній, мнестичній, емоційній сферах; у мовленнєвій діяльності (поява розуміючої функції мовлення, інтонаційно оформлених вокалізацій, складів; зростання потреби у спілкуванні, мовленнєвого супроводу дій, активного та пасивного словника, кількості використовуваних лексико-граматичних конструкцій; підвищення розбірливості мовлення, якості виконання артикуляційних вправ, граматичної будови мовлення); 
- III функціонального блоку: нарощування ефективності вольових зусиль; прийняття допомоги дорослого; зниження примхливості, агресивності, не контрольованості поведінки; зміни в характері ігрової діяльності (перехід від маніпуляцій до розгляду іграшок, поява елементарних ігрових дій, вдосконалення сюжету).

Перші практичні успіхи у використанні нейростимуляційного методу довели i переконали нас в тому, що транскраніальна мікрополяризація забезпечує активацію сприймаючої функції нейроні та підвищення пластичної функції мозку.

Отже, транскраніальна мікрополяризація у дітей із різними типами мовленнєвого дизонтогенезу активує мозкову діяльність для обробки мовленнєвої інформації та сприяє розвитку здатності планувати мовленнєву діяльність і стабілізувати поведінкові реакції.

Варто відзначити, що в арсеналі українських наукових досліджень існує низка досліджень, спрямованих на з'ясування психофізіологічного стану дітей після використання технологій мозочкової стимуляції, зокрема: використання балансувальної дошки доктора Френка Белгау в навчально-корекційній роботі 3 учнями 1-4 класів із порушеннями психофізичного розвитку (О. Кочерга, В. Шорохова) [6]; вивчення сформованості фізичних якостей у дітей із порушеннями функцій опорно-рухового апарату засобами баламетрики (А. Заплатинська, В. Каліна, А. Л. Сиротюк, А. С. Сиротюк та ін.) [4; 6].

Вивчивши вітчизняний і зарубіжний теоретичний і практичний досвід використання програм мозочкової стимуляції ми вирішили апробувати іiі в нейрологокорекційній роботі 3 дітьми дошкільного віку з тяжкими порушеннями мовлення первинного і вторинного генезу (на тлі розладів аутистичного спектра і затримки психомоторного і психомовленнєвого розвитку).

Для оцінки ступеня сформованості функцій мозочка використовували рухові проби $\mathrm{i}$ вправи на приладі «Постурограф». За результатами дослідження рухових проб нами встановлена дисфункція мозочка, яка проявлялася в недорозвиненні координаційного механізму управління довільними рухами особливо у дітей із затримкою психомоторного i психомовленнєвого розвитку. У дітей із моторною алалією спостерігалися дизритмічність, дизамплітудность і труднощі переключення при виконанні довільних рухів, порушення регуляції м'язового тонусу. Постурографія ж дозволила нам оцінити роботу мозку по інтеграції слухової, зорової та пропріоцептивної інформації при виконанні вправ на рівновагу. На основі отриманих даних була розроблена нейрологокорекційна програма розвитку функцій мозочка.

В рамках розробленої нейрологокорекційної програми розвитку функцій мозочка у дітей із тяжкими порушеннями мовлення первинного і вторинного генезів (на тлі розладів аутистичного спектра i затримки психомоторного i психомовленнєвого розвитку) ми використовували такі засоби мозочкової стимуляції: балансувальну дошку Ф. Белгау, систему Balance Master та інтерактивну платформу Wii Fit. Заняття проходили щодня. Повний цикл залежав від індивідуальних рухових можливостей і віку дітей, але в середньому складався 35 циклічних повторів по 20 занять 3 перервою на 2 тижні. Індивідуальна програма передбачала виконання вправ на координацію рухів, в тому числі візуально-моторних координацій, збереження рівноваги і регуляцію м'язового тонусу. Виконання вправ на балансувальній дошці, розробленої Ф. Белгау ще на початку 60 -х років $\mathrm{XX}$ століття, сприяли не тільки розвитку функцій мозочка, а й удосконаленню пізнавальних навичок. Діти, стоячи на дошці, лавці, будьякій нерівній поверхні, називали кольори, тварин, птахів, рослини тощо. Метою виконання вправ була стимуляція і нормалізація роботи мозочка. 3 огляду на те, що мозочок анатомічно $\epsilon$ структурою першого функціонального блоку О. Лурія (енергетичного), виконання вправ також сприяло активації і підтримці тонусу кори головного мозку, а значить підвищенню концентрації уваги, поліпшенню первинної інтеграції сенсомоторної інформації, регулюванню мотиваційних і емоційних станів. Результати повторних рухових проб і виконання вправ на приладі «Постурограф» доводять ефективність використання технологій мозочкової стимуляції в процесі організації логокорекційної допомоги.

Таким чином, ми переконалися, що технологія мозочкової стимуляції забезпечує формування базових навичок для прийому, обробки і засвоєння інформації, яка надходить у головний мозок із внутрішнього і зовнішнього середовища, активізації уваги, підвищує ефективність логокорекційних занять. Перші практичні успіхи у використанні нейрологокорекційних технологій, спрямованих на активізацію пластичних функцій мозку, дають надію на широке та ефективне впровадження знань нейронаук у практику спеціальної освіти. 
Вивчивши зарубіжний теоретичний i практичний досвід використання нейростимуляційних технологій, ми вирішили апробувати технологію Interactive Metronome в системі надання корекційно-розвиткових послуг учням із різними типами мовленнєвого дизонтогенезу. Суб'єктами стали школярі початкових класів із тяжкими порушеннями мовлення первинного і вторинного генезу (на тлі розладів аутистичного спектра, затримки психомоторного і психомовленнєвого розвитку, порушень опорно-рухового апарату тощо).

Високотехнологічна методика, розроблена кампанією Interactive Metronome, рекомендована для використання у комплексній корекційно-розвитковій діяльності 3 дітьми із дистаксією, дизритмією, диспраксією різного генезу (затримкою мовленнєвого та психічного розвитку, дислексією та дисграфією, порушеннями темпо-ритмічної сторони мовлення, дитячим центральним паралічем, синдромом дефіциту уваги та гіперактивністю, розладами аутистичного спектра тощо). Заняття за цією технологією проходили щодня. Повний цикл залежав від індивідуальних можливостей і віку учнів, але в середньому складався 34 циклічних повторів по 50 занять 3 перервою на 2 тижні. Індивідуальна корекційна програма передбачала виконання вправ 3 допомогою сенсорної рукавички або сенсорного килимка, спрямованих на стимуляцію синхронізації рухів ніг і рук через звукові ритмічні сигнали в навушниках інтерактивного метроному. Дитина бачила на екрані монітора, наскільки точно вона виконує завдання. Саме завдяки тому, що інтерактивний метроном забезпечував зворотний зв'язок, слуховий і візуальний, учень мав змогу коригувати власні рухи. Заняття проводилися під керівництвом нейрологопеда.

Метою виконання вправ була стимуляція і нормалізація роботи мозочка, системи базальних ядер. 3 огляду на те, що мозочок і базальні ядра анатомічно $\epsilon$ структурою першого (енергетичного) функціонального блоку за О. Лурія, виконання вправ також сприяло активації і підтримці тонусу кори головного мозку, а значить підвищенню концентрації уваги, поліпшенню первинної інтеграції сенсомоторної інформації, регулюванню мотиваційних і емоційних станів.

Результати академічної та соціальної успішності учнів із особливими потребами довели ефективність використання нейростимуляційної технології Interactive Metronome в процесі організації корекційно-розвиткових послуг. Ми переконалися, що ця технологія забезпечує формування базових навичок для прийому, обробки і засвоєння інформації, яка надходить у головний мозок 3 внутрішнього $\mathrm{i}$ зовнішнього середовища, активізацію уваги, підвищує ефективність корекційно-розвиткових занять. Використання даної технології покращують якість моторного та мовленнєвого планування, темпо-ритмічної організації мовлення, діяльності вищих психічних функцій. Перші практичні успіхи у використанні нейростимуляційних технологій, спрямованих на активізацію пластичних функцій мозку, дають надію на широке та ефективне впровадження наукових знань в практику інклюзивного навчання.

Таким чином, інтерактивний метроном активує мозкову діяльність для обробки сенсорної i моторної інформації та сприяє розвитку здатності планувати діяльність i стабілізувати поведінкові реакції.

Нейропсихологічна корекція 3 інтегрованою програмою сенсорної інтеграції та антигравітації. Використання зорового, слухового, пропріоцептивного, вестибулярного, балансувального, координаційного обладнання сприяє розвитку спроможності нервової системи до обробки, інтеграції і модуляції сенсорномоторних сигналів, формуванню у дітей базових психологічних структур розвитку особистості та якісному підвищенню нейродинамічних показників психічної діяльності. Це підтверджено дослідженнями Джин Айpec, А. Банди, W. Dunn, J. Kerr, B. Knickerbocker, S. Lane, Ш. Лейн, D. McIntosh, L. Miller, Э. Мюррей, D. Parham, C. Royeen, C. Summer та ін.).

Таким чином, використання фізіотерапевтичних технологій у логокорекційній діяльності дітей із різними типами мовленнєвого дизонтогенезу сприяє активації сприймаючої функції нейронів, підвищенню нейрональної активності структур мовномовленнєвого механізму, активізації механізмів саморегуляції, що призводить до ефективної компенсації пошкоджених (або недорозвинених, або спотворених, або дефіцитарних) ланок функціональної системи мови та мовлення.

Нейроакустичні технології

Досягнення нейроакустиків (Т. Будзинські), довели позитивний вплив звуку на гармонізацію діяльності головного мозку. Сучасні технології нейроакустичної стимуляції використовують у комплексній корекційно-розвитковій роботі з дітьми, які мають мовленнєві, 
когнітивні, моторні та поведінкові порушення. До таких технологій відносять: метод Альфреда Томатіса (1957), Алекса Домана «The Listening Program» (1998), метод слухової терапії inTime (2009), В. Тарасенко «Високачастотна терапія звуком» (2011).

Механізм нейросенсорної слухової стимуляції за методом А. Томатіса полягає в тому, що завдяки повітряній та кістковій провідності спеціально оброблених музикальних мелодій стимулюються м'язи середнього вуха, що призводе до активності внутрішнього вуха, вестибулярного апарату, ретикулярної формації, мозочка та лобних ділянок мозку.

Поряд із методикою нейроакустичної стимуляції А. Томатіса, існує аудіостимулююча програма кампанії Advanced Brain Technologies «The Listening Program» (1998), автором якої є А. Доман. The Listening Program (далі - TLP) є інноваційним методом музикальної терапії, що зміцнює нейронні мережі з метою розвитку їх здатності до обробки інформації та комунікації.

Метод слухової терапії inTime (2009), розроблений працівниками кампанії Advanced Brain Technologies під керівництвом А. Домана, забезпечує гармонізацію зон головного мозку з допомогою музики, ритму та рухово-ритмічних вправ. Прослуховування спеціальних ритмічних аудіозаписів поряд із виконанням фізичних вправ дозволяє виробити відчуття ритмічності, уваги через синхронізацію діяльності нейронних мереж.

Для підвищення швидкості розуміння зверненого мовлення розроблені програми високочастотної акустичної терапії. Високочастотні звуки $є$ фізкультурою для нейроепітелія м'язів внутрішнього вуха та кори головного мозку. Періодичність використання високих i низьких частот тренує вухо чути, а мозок - сприймати.

На Україні, в рамках класичної логокорекційної роботи 3 дітьми із сенсорною та сенсомоторною алалією, розладами аутистичного спектра, затримкою мовленнєвого розвитку за алалічним типом, затримкою психомовленнєвого розвитку, системним недорозвиненням мовлення, використовуються комп'ютерні програми нейроакустичної стимуляції «Електронне вухо. Домашній логопед», «Домашній логопед - дефектолог», що розроблені українською вченою B. Тарасенко спільно з американською кампанією Avid. Також нею запатентовано методику «Високачастотна терапія звуком» (2011). Методологічним підгрунтям створення програм слугувала теорія А. Томатіса (1957) про відновлення пошкоджених клітин мозку засобами високочастотного звуку. Обов'язковою умовою при реалізації цих програм є одночасне використання спеціальних стереонавушників із кістковою та повітряною провідністю. Також, за методиками А. Томатіса та В. Тарасенко, в програмах високочастотної терапії звуком використовуються три види стимуляції: аудіальна, візуальна та вібраційна стимуляції.

Аудіальна передбачає стимуляції:

- ритмом (стимуляція мовленнєвої уваги через зміну ритму творів);

- зонуванням (стимуляція клітин головного мозку, які потребують дозрівання, через подачу сигналів на 4 зони мозку обох півкуль);

- затримкою часом (стимуляція провідної в обробці інформації півкулі через затримку подачі сигналу);

- затримкою подачі (стимуляція нейронної мережі, яка здійснює обробку фонематичної інформації, через різну подачу сигналу у стереонавушники із кістковою провідністю та звичайні навушники); навушниках);

- гучністю (стимуляція каналу сприйняття інформації завдяки різниці гучності у

- масажними рухами (стимуляція глибинних структур мозку масажними рухами у корі головного мозку через поперемінну подачу сигналів);

- тривалістю впливу (максимальна стимуляція зон кори завдяки тривалості програм впливу).

Візуальна стимуляція відбувається через зміну яскравості екрану з частотою, близькою до альфа ритму або бета ритму, завдяки чому активізуємо відновлення власних процесів, пов'язаних із мовленням, та стимулюємо якість і швидкість обробки інформації.

Під час реалізації методики високачастотної терапії звуком В. Тарасенко рекомендує дотримуватися таких умов: врахування провідної півкулі, зручний час проходження щоденної стимуляції, використання мовленнєвої стимуляції у поєднанні з музикальним матеріалом, одночасна стимуляція декількох зон головного мозку, проведення в домашніх умовах, що значно знижує фактор напруження дитини. 
Таким чином, завдяки одночасній стимуляції чотирьох слухових каналів, двох зорових та одного вібраційного каналу, відмічається позитивна динаміка у функціональному розвитку кіркових та підкіркових структур головного мозку. За результатами впровадження системи нейротренувань за методиками А. Томатіса та В. Тарасенко, унормовуються темпи дозрівання функціональної системи мови та мовлення та підвищується якість ії функціонування.

Сучасним немедикаментозним методом корекції порушених функцій мовлення є метод біологічного зворотнього зв'язку (БОС), спрямований на цілеспрямовану активізацію резервних можливостей організму з використанням сучасної електронної апаратури. Запроваджений в галузі медицини з 50-х років XX століття. Теоретично метод грунтується на теорії функціональних систем П. Анохіна та теорії стійких патологічних станів Н. Бехтєрової. Комп'ютерний ігровий тренажер БОС дозволяє сформувати стійкий навик діафрагмально-релаксаційного дихання, довільної регуляції дихання (сили, тривалості, плавності повітряного струменя), темпо-ритмічної організації мовлення (темп, ритм, інтонація, модуляція, паузація, наголос) та емоційної зацікавленості.

Дослідження Е. Джекобсон, У. Кеннон, Н. Мілер, В. Чернігівського, О. Сметанкіна (1999), І. Поварової (1988), С. Чернобельського (1996), М. Теречева (2002) довели позитивний корегуючий вплив методу на навчання логопата навичкам саморегуляції та синхронізації дихання, артикуляції та голосоподачі.

Таким чином, використання нейроакустичних технологій у логокорекційній діяльності сприяє синхронізації взаємодії між зонами головного мозку, підвищуючи якість функціонування структур мозку в цілому.

\section{Використання нейрологопедичних технологій}

Комп’ютерна корекційна методика Fast For Word (1996) розроблена провідними спеціалістами кампанії Scientific Learning докторами Michael Merzenich, Bill Jenkins, Paula Tallal, Steven Miller. Механізм дії полягає у тренуванні системи слухового сприйняття, повторенні складних фонем, що активує зону Брока та збільшує зону кори, що відповідає за мовні функції [4].

Стимуляцію процесу сприйняття, передачі та обробки слухової інформації проводять за допомогою спеціального приладу Forbrain, який облаштований вібраційним обладнанням для посилення кісткової провідності та унікальним динамічним фільтром для підсилення гучності мовлення високими частотами. При використанні Forbrain дитина чує відкорегований приладом свій голос та голос педагога в акустично модифікованому вигляді, через що мозок перебудовує діяльність у відповідь на зміни. Це сприяє не лише покращенню обробки інформації, а й покращує якісні характеристики голосу та мовлення.

Програма Speechleader $є$ апаратно-програмним продуктом кампаніï linguistic Correction Center i рекомендована для використання у логокорекційній роботі з дітьми та дорослими, які мають дизартрію, алалію, дислексію, дисграфію, загальне недорозвинення мовлення, затримку мовленнєвого розвитку, заїкуватість. Завдяки повторенню за диктором мовленнєвого матеріалу стимулюється та відновлюється повний мовленнєвий цикл: бачу - чую - повторюю - сую себе. У дитини поліпшуються процеси сприйняття мовлення та його моторна реалізація, знімаються або мінімізуються мовленнєві зажими та судоми, поліпшується слухомовленнєва пам'ять. В цілому, стимулюючи обидва канали проведення мовленнєвослухової інформації досягається єдність роботи мовленнєвих зон з мозолистим тілом.

Динамічну електронейростимуляцію (ДЕНС-терапія) використовують в логопедичній практиці як додатковий ефективний засіб стимуляції безумовних рефлексів (жування, ковтання, слиноутворення), поліпшення зорово-моторної координації, мімічного, артикуляційного праксису; нормалізації тонусу м'язів, що беруть участь в утворенні звуків; подолання порушень звуковимови (Н. Бурачевська, О. Бурачевська, С. Гузенко, Ю. Зданович, О. Кузьмінова, Н. Лисецька, Л. Чекунова). Дослідженнями Н. Бурачевської, О. Бурачевської доведено, що впливаючи на сегментарні та рефлексогенні зони, акупунктурні точки, у дитини з'являються нові компенсаторні реакції, які відновлюють гомеостатичну рівновагу [2]. Саме завдяки рефлекторним і нейрохімічним реакціям в організмі дитини запускається низка регуляторних та адаптаційних механізмів [2]. Авторами розроблено методику використання динамічної електронейростимуляції в корекції мовленнєвих порушень різного ступеня тяжкості та доведено позитивний вплив на лише на підвищення мовленнєвої активності, а й на інтелектуальний та мовленнєвий розвиток $[1 ; 2]$. О. Архіпова рекомендує нейростимуляцію використовувати дітям із труднощами постановки звуків, автоматизації звука у складах, словах і зв'язному мовленні, розбірливості мовлення. 
Біоенергопластика поряд 3 артикуляційною гімнастикою також $\epsilon$ засобом нейростимуляції кінестетичної аферентації, кінцевою метою якої $є$ створення позитивних кінестезій в артикуляційних м'язах та укладах.

Таким чином, використання нейрологопедичних програм у логокорекційній діяльності $\epsilon$, по-перше, науково обгрунтованими та сертифікованими; по-друге, активують нейронні мережі мовномовленнєвокомунікативного механізму; по-третє, дозволяють компенсувати нестабільність роботи центральної нервової системи; по-четверте, розвивають резерви головного мозку за рахунок яких відбувається розвиток дитини; по-п'яте, поліпшується психосоматичне здоров’я та підвищується стійкість нервової системи; по-шосте, активують вищі психічні функції та підвищують когнітивну активність. Також нейростимуляція сприяє розвитку пізнавальних навичок, тобто сукупності розумових здібностей та процесів сенсомоторної інтеграції. Завдяки їх використанню долається дефіцитарність та несформованість певних ділянок мовномовленнєвокомунікативного механізму в онтогенезі.

Висновки. 1. Сучасна логопедична практика має в своєму арсеналі традиційні та нетрадиційні технології, які спрямовані не лише на максимальну мовленнєву корекцію, а й на когнітивний, моторний розвиток дитини. Логопедія, знаходячись на межі лінгвістики, психології та медицини, все більше адаптує досягнення медицини до своїх потреб, які допомагають оптимізувати роботу вчителя-логопеда.

2. Новітні нейрокорекційні технології в логопедії не можна розглядати як самостійні, вони розглядаються як частина загальноприйнятих перевірених часом технологій. Нові засоби взаємодії логопеда 3 дитиною, нові стимули слугують створенню сприятливого емоційного фону, сприяють включенню в роботу збережених та активізації порушених психічних функцій.

3. Використання у логокорекційній роботі нейростимуляційних технологій є новою сходинкою в оптимізації процесу корекції мовлення дітей, передумовою для подальшого використання класичних прийомів логопедичної допомоги та кроками у досягненні максимально можливих результатів у подоланні мовленнєвих порушень.

\section{REFERENCES}

1. Бурачевская О. В., Бурачевская Н. И. Динамическая электронейростимуляция в коррекции речевых нарушений. Школьная педагогика. Москва, 2017. № 2 (9). С.5-10.

2. Гузенко С. В. Дэнас терапия в комплексной нейрологопедической коррекции. Научно-практический электронный журнал Аллея Науки. Москва 2017. № 15 (1). С. 269-273.

3. Дегтяренко Т. В., Павлова Н. В. Актуальність міждисциплінарного та нейропсихологічного підходів до діагностики тяжких порушень мовлення у дітей раннього віку. Наука і освіта. Одеса, 2016. № 8. С. 30-37.

4. Заплатинська А. Б. Вивчення сформованості фізичних якостей у дітей 3 порушенням функцій опорно-рухового апарата засобами баламетрики. Збірник наукових. пращь «Освіта осіб з особливими потребами: шляхи розбудови». Київ, 2017. С. 105-112.

5. Ефимов О. И. 15 мифов о детской речи. Диалоги невролога и логопеда о детской речи. М.-С-П.: «Диля», 2016. 223 с.

6. Кочерга О. В. Використання балансувальної дошки доктора Френка Белгау в навчально-корекційній роботі з учнями 1-4 класів із порушеннями психофізичного розвитку. Київ: Видавничий дім «Слово», 2015. 64 с.

7. Микрополяризация у детей с нарушением психического развития / ред. Н. Кожушко. Спб.: «КАРО», 2011. $336 \mathrm{c}$.

8. Мутовин Г. Р., Жилина С. С., Умаханова 3. Р. Нейроонтогенез и его нарушения. Детская больница. Москва, 2009. № 2. С.36-43.

9. Павлова Н. В. Доцільність використання звукових нейромодуляцій в практиці ранньої корекції тяжких порушень мовлення у дошкільнят. Збірник наукових праџь «Актуальні питання корекційної освіти (педагогічні науки)». Кам’янець-Подільський: «ПП Медобори-2006», 2016. Вип. 7. Т.1. С. 302-316.

10. Павлова Н.В. Формування комунікативної активності у немовленнєвих дітей молодшого дошкільного віку засобами інноваційних технологій: дис...канд. пед. наук: 13.00.03. Одеса, 2017. 209 с.

11. Шелякин А.М., Преображенская И.Г., Богданов О.В. Микрополяризационная терапия в детской неврологии (практическое руководство). М.: «Медкнига», 2008. 120 с.

12. Шеремет М.К., Макухова Т.В. Міждисциплінарний синтез теоретичних досліджень у збагачення методологічної бази логопедії. Освіта та педагогічна наука. Київ, 2012. Вип. 4. С. 58-62.

13. Щорічна доповідь про стан здоров'я населення, санітарно-епідемічну ситуащію та результати діяльності системи охорони здоров'я (2017). URL: http://www.uiph.kiev.ua/dawnload/Vidavnictvo/Shchorichna\% 20dopovid/\%D0\%A9\%D0\%BE\%D1\%80\%D1\%96\%D1\%87\%D0\%BD $\%$ D0 $\%$ B0 $\% 20 \% \mathrm{D} 0 \% \mathrm{~B} 4 \% \mathrm{D} 0 \% \mathrm{BE} \% \mathrm{D} 0$ $\%$ BF\%D0\%BE\%D0\%B2\%D1\%96\%D0\%B4\%D1\%8C.2017.pdf 